\title{
PEMANFAATAN MEDIA SOSIAL DALAM PELAYANAN REFERENSI 2.0 DI INDONESIA
}

\author{
Ahmad Anwar*
}

Pengutipan: Anwar, A. (2016). Pemanfaatan media sosial dalam pelayanan referensi 2.0 di Indonesia. Jurnal Ilmu Perpustakaan, Informasi, dan Kearsipan Khizanah Al-Hikmah, 4(1), 57-64.

\author{
*Pustakawan di Akademi Keperawatan Notokusomo Yogyakarta \\ ${ }^{*}$ Mahasiswa Pascasarjana UIN Sunan Kalijaga \\ (aan_whn@yahoo.com)
}

\begin{abstract}
ABSTRAK
Pada era mobile ini telah terjadi perubahan paradigma layanan perpustakaan, di mana perpustakaan dituntut untuk bisa menyediakan layanan berbasis Web 2.0. Pada kenyataanya layanan perpustakaan berbasis Web 2.0 masih sering dimanfaatkan hanya sebagai media informasi dan promosi. Guna optimalisasi pemanfataan Web 2.0 di perpustakan maka salah satu jalan adalah inovasi layanan. Layanan referensi sebagai bagian yang tidak terpisahkan dari perpustakaan yang berfungsi untuk menjawab pertanyaan yang diajukan pemustaka pada dasarnya dapat melakukan inovasi. Dengan bantuan media sosial maka layanan referensi seharusnya dapat dilakukan secara online. Ada berbagai tawaran media sosial yang digunakan sekaligus contoh pemanfaatannya. Walaupun dengan berbagai kendala yang dihadapi ini diharapkan konsep Referensi 2.0 mampu berjalan optimal sekaligus mampu membangun komunikasi efektif antara pustakawan referensi dengan pemustaka.

Kata Kunci: Perpustakaan 2.0, Web 2.0, Layanan referensi, Media sosial
\end{abstract}

\section{ABSTRACT}

In today era, there is a change of paradigm in organizing library in which a library is supposed to provide Web 2.0. In fact, its kind of service is used only for a medium to inform and promote library in general. To optimilize its Web 2.0 within the library, it is therefore the library needs to think of library services innovation. Reference service as a part of library must be playing an important role to optimize its service, or in the other words, they might think innovatively. With the growing rapid of usage os sosial media, the service should be worked in online. There are many sosial media today. The current study is aimed to discover the implementation of Web 2.0 in Indonesia.

Key words: Library 2.0, Web 2.0, Reference service, Sosial media

\section{PENDAHULUAN}

Perpustakaan sebagai sebuah institusi yang berkembang sebagaimana prinsip dari hukum ke tiga dari "Five New Laws Of Librarianship" yaitu use technology intelligently to enhance service (gunakanlah teknologi secara cermat dan cerdas untuk meningkatkan layanan) telah menimbulkan paradigma baru untuk sebuah layanan di perpustakaan modern. Telah terjadi perubahan model layanan dimana saat ini teknologi informasi telah ikut memperlancar arus informasi di perpustakaan. Saat ini pelayanan di perpustakaan sangat dimungkinkan 
dilakukan tanpa melalui tatap muka secara langsung.

Perkembangan dari Library 2.0 telah memungkinkan pustakawan untuk lebih pro-aktif dalam melakukan pelayanan. Tuntutan saat ini perpustakaan harus bisa mengembangkan layanan yang cepat dan dinamis. Dalam kaitannya dengan pelayanan referensi sebagaimana fungsi layanan referensi, yaitu sebagai perantara antara kebutuhan informasi pemustaka dengan sumber informasi yang dimiliki perpustakaan, telah mengalami sebuah perubahan yang dipengaruhi oleh dinamika web 2.0. Pelayanan referensi saat ini tidak terlalu menekankan lokasi dikarenakan saat ini dengan bantuan teknologi informasi telah memungkinkan untuk pelayanan jarak jauh. Para pemustaka bisa memeperoleh layanan melalui pesan singkat atau sarana lain (Widyawan, 2012:13).

Fenomena yang terjadi saat ini di perpustakaan Indonesia adalah penggunaan media sosial sebatas sebagai sarana komunikasi dan promosi perpustakaan ke pemustaka. Padahal di sisi lain seharusnya selain kedua hal tersebut, media sosial bisa digunakan untuk melakukan pelayanan referensi jarak jauh atau lebih dikenal dengan Reference 2.0. Untuk itu perlu disusun sebuah konsep tentang pemanfaatan media sosial apa saja beserta kegunaannya guna mendukung terciptanya pelayanan Reference $2.0 \mathrm{di}$ Indonesia.

\section{TINJAUAN PUSTAKA}

\section{a. Media Sosial}

Dari survei Taylor \& Francis (2014) lebih dari $70 \%$ dari perpustakaan menggunakan media sosial, dan $60 \%$ diantaranya telah memiliki akun media sosial selama tiga tahun atau lebih. Terdapat setidaknya $30 \%$ dari pustakawan melakukan posting setiap hari. Dalam survey ini Facebook dan Twitter menjadi media popular yang digunakan, tetapi pemanfaatan media sosial lain juga dengan cepat berkembang, terutama untuk saluran visual seperti YouTube, Pinterest dan Snapchat.

Perpustakaan menggunakan media sosial untuk memenuhi berbagai tujuan, dengan sebagian besar difokuskan pada promosi. Namun komunikasi dengan pemustaka bisa semakin intens. dikarenakan saat ini media sosial dilengkapi dengan komunikasi dua arah yang dirancang untuk mengumpulkan umpan balik (misalnya untuk pengembangan koleksi). Selain itu dengan media sosial perpustakaan dapat membangun layanan secara real-time karena keterlibatan dari pemustaka. Di sisi lain, media sosial juga semakin dilihat sebagai alat untuk manajemen koleksi (Taylor \& Francis, 2014: 2).

Menurut Meredith G. Farkas (2007) media sosial, secara umum dalam pemanfaatannya memiliki 9 karateristik yang dirinci sebagai berikut:

1) Kemudahan dalam membuat dan membagikan konten

Dengan menggunakan sosial media siapa pun dapat membuat konten online, termasuk foto, teks, audio, dan video. Kemudian dengan mudah dan cepat dapat menyebarkanya.

\section{2) Kolaborasi online}

Kolaborasi dalam menulis konten sangat mudah untuk dilakukan oleh siapapun, di manapun dan kapanpun. 
Dengan wiki, siapa pun dapat menambahkan atau merubah isi artikel. Wiki juga dapat digunakan bersama-sama untuk mengembangkan panduan atau basis pengetahuan.

3) Percakapan dapat dibagikan secara realtime

Media sosial memungkinkan percakapan terjadi dalam berbagai bentuk. Dengan media sosial sebuah komunikasi terjadi dan seketika itu juga dapat dibagikan secara real-time.

\section{4) Masyarakat berkembang dari bawah ke atas}

Media sosial membantu kita membangun berbagai jenis masyarakat. Saat ini banyak masyarakat online yang tidak lagi memerlukan forum, papan buletin, atau email. Percakapan bisa berlangsung di wiki, di bagian komentar blog, atau melalui berbagai software media sosial. Komunitas seperti ini terbentuk karena adanya beberapa orang yang menggunakan media sosial yang sama atau mempunyai fokus kegiatan atau hobi serupa.

\section{5) Memanfaatkan kebijaksanaan dari banyak orang}

Tidak hanya dapat berkomunikasi, berkolaborasi, dan membangun komunitas online, tapi kita bisa belajar banyak dari pengetahuan dan perilaku orang karena lebih banyak orang berpartisipasi dalam media sosial.

\section{6) Transparan}

Dengan media sosial sebuah perpustakaan dapat terhubung dengan pemustakanya secara pribadi dan dapat diketahui oleh semua orang. Tidak ada hal yang ditutup-tutupi dengan menggunakan media sosial.

\section{7) Personalisasi}

Dengan teknologi RSS telah memungkinkan seseorang untuk berlangganan artikel secara tertentu sesuai dengan topik yang dia inginkan, hal ini bisa.

\section{8) Portabilitas}

Semua media sosial selalu terhubung dengan internet sehingga memungkinkan setiap orang untuk mengaksesnya secara 24 jam dimanapun dan kapanpun itu, dengan syarat pengguna terhubung dengan jaringan internet.

\section{9) Mengatasi Hambatan Jarak dan Waktu}

Media sosial mempunyai manfaat yang sangat baik untuk mengatasi hambatan jarakdan waktu, sekaligus memberikan kesempatan orang untuk berkomunikasi dan bekerja sama dimanapun mereka berada.

Sembilan karateristik media sosial ini telah memainkan peran penting sehingga telah mengubah pandangan seseorang untuk bisa berkomunikasi. Komunikasi saat ini dapat terjadi tanpa tatap muka, dan komunikasi bahkan dapat diketahui dan oleh banyak orang dalam satu waktu.

\section{b. Referensi 2.0}

Pelayanan referensi sebagai bagian dari layanan perpustakaan telah mengalami dinamika perkembangan yang pesat terutama dipengaruhi dengan perkembangan teknologi informasi. Perubahan ini banyak dipengaruhi oleh konsep Web 2.0 kemudian diadopsi oleh perpustakaan ke dalam konsep Library 2.0 
dan kemudian mempengaruhi pelayanan referensi menjadi Referensi 2.0. Apabila dilihat dari model layanannya, apabila layanan referensi menggunakan prinsip Web 2.0 maka dapat disebut dengan layanan Referensi 2.0 (Tajer, 2009:25-27).

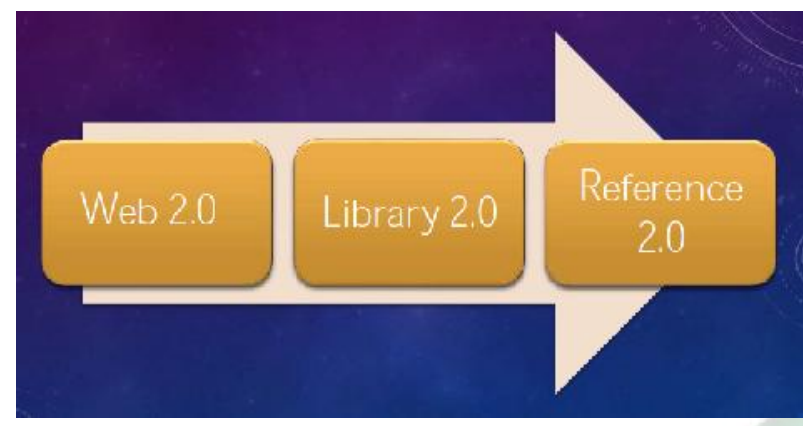

Gambar 1.

Perkembangan layanan Referensi 2.0 (Sumber: Juan 2014)

Adapun berbagi media sosial yang dapat dimanfaatkan dalam pelayanan Referensi 2.0 adalah sebagai berikut :

1) Instant Massaging (IM). Pustakawan referensi dapat mengirim teks, video dan file audio seperti file instruksi perpustakaan, sumber referensi melalui IM.

2) Wiki. Pustakawan referensi dalam melaksanakan tugas-tugas referensi seperti pemilihan dan evaluasi sumber referensi, ketentuan bibliografi, katalog bersama dan pedoman dapat dialkukan dengan menggunakan Wiki.

3) Blogs. Melalui media blog pustakawan referensi dapat memperkenalkan referensi ke pengguna seperti tentang waktu dan lokasi layanan referensi, kemudian memperkenalkan sumber referensi yang disediakan dan sumber referensi yang baru.

4) RSS. Dengan menciptakan RSS feed bagi pengguna untuk berlangganan maka pemustaka dapat memperoleh data seperti update data koleksi referensi terbaru.
5) Podcasting. Pustakawan dapat memanfaatkan podcasting seperti untuk memberikan tutorial perpustakaan atau melakukan wawancara.

6) Tagging. Pengguna dapat menandai sumber referensi favorit mereka dengan memanfaatkan Tagging. Dengan teknologi ini juga memungkinkan pengguna untuk mereview dan mengidentifikasi sumber informasi referensi yang ditandai orang lain. Hal yang menarik adalah pengguna dapat merekomendasikan sumber informasi referensi satu sama lain.

7) Social Networking Sites (SNS). Pengguna dapat membuat account untuk berinteraksi dengan layanan referensi perpustakaan. pengguna juga dapat merekomendasikan sumber informasi referensi pada orang lain pada SNS yang sama.

8) Mashups. Dengan menggunakan wiki, blog, IM, RSS, dll secara sinkron, maka perpustakaan akan menciptakan sebuah mashup. Mashup adalah gabungan dari berbagai aplikasi web.

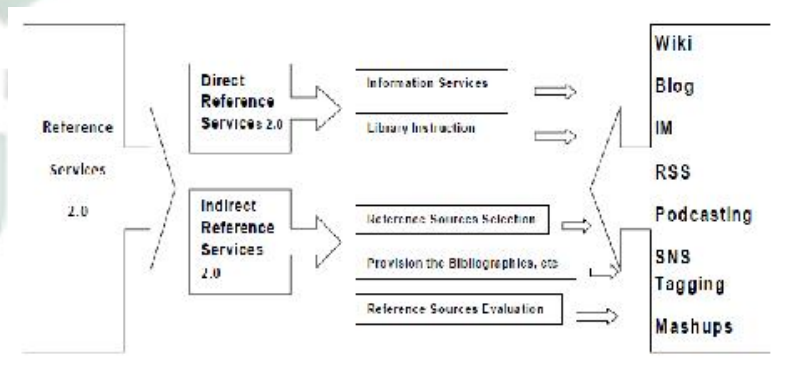

Gambar 2.

Fitur Referensi 2.0 (Sumber: Tajer 2009)

\section{PEMBAHASAN}

a. Konsep Pemanfaatan Media Sosial Sebagai Layanan Referensi 2.0

Secara ketugasan pustakawan referensi tidaklah hanya menjawab 
pertanyaan substantif dari pemustaka melainkan juga mempunyai kewajiban untuk membimbing pemustaka agar bisa memilih dan mengunakan sarana yang tepat untuk menelusur informasi. Seorang pustakawan referensi harus bisa mengarahkan pemustaka ke sumber informasi, membantu mereka mengevaluasi, bahkan merujuk sumber informasi di luar perpustakaaan (Widyawan, 2012:2). Ketugasan ini dapat melalui tatap muka maupun tidak. Dalam konsep Referensi 2.0 layanan dapat diberikan tanpa melalui proses tatap muka.

Layanan Referensi 2.0 didasari pada fenomena yang muncul dari masyarakat pengguna yang dilayani. Saat ini masyarakat pengguna menginginkan segala informasi secara cepat atau sering disebut dengan masyarakat generasi mobile. Untuk memenuhi kebutuhan informasi secara cepat tanpa pengguna harus hadir secara fisik ke perpustakaan, perpustakaan telah melakukan beberapa inovasi layanan. Sebagai salah satu inovasi tersebut adalah dengan menggunakan media sosial sebagai sarana yang membantu layanan. Terdapat beberapa alasan mengapa perpustakaan memilih media sosial seperti di antaranya yaitu penghematan biaya, distribusi informasi yang cepat, meningkatkan interaksi pengguna, dan promosi konten.

Adapun berdasarkan data statistik yang dirilis dalam www.statista.com ada sepuluh media sosial yang menempati rangking tertinggi. Adapun sepuluh media sosial tersebut adalah Facebook, WhatsApp, QQ, Facebook Messenger, Qzone, WeChat, Instagram, Twitter, Baidu Teiba, dan Skype. Dari kesepuluh media sosial tersebut berdasarkan pengamatan penulis hanya ada lima yang aktif digunakan oleh perpustakaan di
Indonesia yaitu Facebook, WhatsApp, Facebook Messenger, Instagram, dan Twitter.

Sebelum menentukan konsep layanan yang sesuai terlebih dahulu perlu mengenal masing-masing karateristik dan fungsi penggunaan dari setiap media sosial.

\section{1) Facebook}

Facebook dibuat pada 4 February 2004, facebook membantu kita untuk saling terhubung dengan orang lain. Facebook memungkinkan pengguna dapat membuat profil dilengkapi foto, daftar ketertarikan pribadi, informasi kontak, dan informasi pribadi lain. Pengguna dapat berkomunikasi dengan teman dan pengguna lain melalui pesan pribadi atau umum dan fitur obrolan. Mereka juga dapat membuat dan bergabung dengan grup yang disukai dan "halaman kesukaan.

\section{2) WhatsApp}

Merupakan aplikasi yang digunakan dalam smart phone dimana setiap orang dengan memanfaatkan internet untuk mengirim dapat mengirim pesan teks, gambar, video, lokasi pengguna dan pesan $m$ audio ke pengguna lain menggunakan nomor ponsel seluler standar.

\section{3) Facebook Messenger}

Facebook Messenger adalah layanan pesan dari aplikasi facebook. Facebook Messenger memungkinkan komunikasi melalui teks, suara dan video. 


\section{4) Instagram}

Instagram merupakan aplikasi berbagi foto online, video-sharing, dan layanan jejaring sosial yang memungkinkan penggunanya untuk mengambil gambar dan video, dan berbagi dengan media sosial lain, seperti Facebook, Twitter, Tumblr, dan Flickr. Fitur khas aplikasi ini adalah bentuk foto dengan bentuk persegi dan rasio 4:3. Durasi maksimum untuk video Instagram adalah 15 detik.

\section{5) Twitter}

Merupakan layanan jejaring sosial yang memungkinkan pengguna untuk mengirim dan membaca pesan 140 karakter pendek yang disebut "tweets". Pengguna terdaftar dapat membaca dan mengirim tweets, tetapi mereka yang tidak terdaftar hanya dapat membacanya. Pengguna mengakses Twitter melalui website, SMS atau aplikasi perangkat mobile

Melihat dari karakteristik dari kelima media sosial tersebut, maka dapat disusun sebuah konsep layanan Referensi 2.0 yang dirangkum dalam tabel di bawah ini.

Tabel 1. Konsep layanan Referensi 2.0

\begin{tabular}{|c|c|}
\hline Media Sosial & Contoh Pemanfaatan \\
\hline Facebook & $\begin{array}{l}\text { 1. Menyebarkan informasi dan } \\
\text { berita tentang layanan } \\
\text { referensi perpustakaan } \\
\text { 2. Memposting buku baru } \\
\text { 3. Berbagi foto } \\
\text { 4. Berbagi video petunjuk } \\
\text { penelusran dan evaluasi } \\
\text { informasi } \\
\text { 5. Mengatur acara dan update } \\
\text { event } \\
\text { 6. Membangun keterlibatan } \\
\text { dengan pengguna } \\
\text { 7. Menjawab pertanyaan } \\
\text { pengguna melalui kolom } \\
\text { komentar }\end{array}$ \\
\hline WhatsApp & 1. Menjawab pertanyaan \\
\hline
\end{tabular}

\begin{tabular}{|c|c|}
\hline & $\begin{array}{l}\text { pengguna melalui pesan } \\
\text { 2. Melakukan penyebaran } \\
\text { kegiatan melalui pesan } \\
\text { broadcast }\end{array}$ \\
\hline $\begin{array}{l}\text { Facebook } \\
\text { Messenger }\end{array}$ & $\begin{array}{l}\text { 1. Menjawab pertanyaan } \\
\text { pengguna melalui pesan } \\
\text { 2. Menjawab pertanyaan } \\
\text { pengguna melalui video call }\end{array}$ \\
\hline Instagram & $\begin{array}{l}\text { 1. Mempromosikan koleksi } \\
\text { referensi perpustakaan } \\
\text { melalui foto } \\
\text { 2. Mempromosikan koleksi } \\
\text { rerferensi perpustakaan } \\
\text { melalui video singkat } \\
\text { 3. Menjawab pertanyaan } \\
\text { pengguna melalui kolom } \\
\text { komentar }\end{array}$ \\
\hline Twitter & $\begin{array}{l}\text { 1. Menyebarkan informasi dan } \\
\text { berita tentang perpustakaan } \\
\text { melalui tweets } \\
\text { 2. Menyediakan layanan } \\
\text { customer service } \\
\text { 3. Menjalin hubungan } \\
\text { interaktif dengan pengguna } \\
\text { 4. Menjalin hubungan dengan } \\
\text { pustakawan dan institusi } \\
\text { lain }\end{array}$ \\
\hline
\end{tabular}

Tabel di atas menunjukkan bawah facebook merupakan sarana yang paling lengkap guna mendukung layanan Referensi 2.0 karena secara karakter mempunyai fasilitas dan kegunaan yang lengkap.

\section{b. Tantangan Pemanfaatan Media Sosial Sebagai Layanan Referensi 2.0}

Seperti halnya penggunaan media sosial secara umum di perpustakaan, ada beberapa tantangan yang bisa menjadi peluang maupun kelemahan perpustakaan dalam sebuah pelayanan Referensi 2.0, yaitu sebagai berikut:

1. Komitmen dari staf dan pimpinan perpustakaan yang kurang,

2. Pengunaan media sosial memerlukan keahlian teknologi dari staf perpustakaan, 
3. Tantangan dalam penggunaan bahasa internasional,

4. Minat dan kemampuan menggunakan media sosial tidak sama antar sesama staf perpustakaan,

5. Keterbatasan dana untuk mendukung penggunaan media sosial secara berkelanjutan,

6. Perpustakaan kesulitan untuk melibatkan pengguna untuk aktif dalam media sosial yang dimiliki perpustakaan,

7. Kesulitan untuk membuat kontenkonten yang menarik di media sosial perpustakaan,

8. Permasalahan hak cipta dalam pengunaan media sosial, sebagai contoh koleksi video, foto, artikel yang diunggah di media sosial,

9. Permasalahan sarana dan prasarana perpustakaan seperti koneksi internet, infrastuktur teknologi dan pembatasan akses yang dilakukan pemerintah.

Melihat tantangan tersebut sangat penting bagi perpustakaan untuk menyediakan sumber daya manusia yang handal yang mampu menggunakan media sosial serta kemamuan teknologi informasi. Serta tidak lupa harus didukung dengan sarana dan prasarana yang memadai.

\section{KESIMPULAN}

Konsep pemanfaatan media sosial dalam pelayanan referensi 2.0 di Indonesia dapat dilakukan dengan mengandalkan lima media sosial yaitu Facebook, WhatsApp, Facebook Messenger, Instagram, dan Twitter. Dari kelima media sosial tersebut facebook mempunyai fitur yang paling lengkap untuk mendukung layanan referensi 2.0. Fungsi utama dari konsep ini adalah mempromosikan kegiatan serta koleksi referensi melalui media sosial yang ada. sekaligus menjawab pertanyaan yang muncul melalui media sosial guna diarahkan menuju informasi dalam perpustakaan atau diluar perpustakaan.

\section{DAFTAR PUSTAKA}

Arya, Harsh Bardhan dan J. K. Mishra. "Oh! Web 2.0, Virtual Reference Service 2.0, Tools \& Techniques (I): A Basic Approach", dalam Journal of Library \& Information Services in Distance Learning, 5:4, 149-171, DOI:

10.1080/1533290X.2011.638819

Farkas, Meredith G. Social Software In Libraries: Building Collaboration, Communication, and Community Online, New Jersey: Information Today. Inc, 2007.

Juan, Elijah John F. Dar, “Using Facebook for Marketing and Reference Service: The University of the Philippines Diliman Library Experience", disampaikan dalam PLAI Congress, 26-28 November 2014 the Century Park Hotel, Malate, Manila.

Ramos, Marian S., "Reference 2.0 in Action: An Evaluation of the Digital Reference Services in Selected Philippine Academic Libraries", makalah disampaikan dalam World Library and Information Congress, 13-18 Agustus, San Juan, Tahun 2011.

Tajer, Pegah, "Reference Services 2.0: A Proposal Model for Reference Services in Library 2.0", Makalah disampaikan dalam 7th International CALIBER 2009 Pondicherry University, Puducherry, February 25-27, 2009.

Taylor dan Francis, (2014). Use of social media by the library current practices and future opportunities. New York: Taylor \& Francis Group. 
Widyawan, R. (2012). Pelayanan referensi berawal dari senyuman, Bandung: Bahtera Ilmu. 